\title{
Reevaluation of Mycobacterium fortuitum (Synonym: Mycobacterium ranae)
}

\author{
J. M. GRANGE and J. L. STANFORD \\ The School of Pathology, The Middlesex Hospital Medical School, \\ London, WIP 7LD, England
}

\begin{abstract}
One hundred strains of Mycobacterium fortuitum ( $M$. ranae) were characterized. Strains now recognized as belonging to the species $M$. chelonei were excluded. Seven serotypes of $M$. fortuitum showed some correlation with cell wall lipids, colony types, temperature tolerance, Bönicke's biotypes, and other properties. Serotype I was frequently associated with disease, whereas serotype II, although common in the environment, never was. $M$. fortuitum subsp. fortuitum and $M$. fortuitum subsp. giae belong to serotypes $\mathrm{I}$ and $\mathrm{V}$, respectively; the other serotypes were not considered worthy of special subspecific designation. A list of the constant and variable characteristics of $M$. fortuitum is given.
\end{abstract}

In 1904 Rupprecht (28) described the occurrence of tuberculosis in a frog, and in the following year Küster (19) cultured the causative organism from such cases. These "frog tubercle bacilli" were named Mycobacterium ranae in the first edition of Bergey's Manual of Determinative Bacteriology in 1923, and this designation was employed in a number of good taxonomic studies by Aronson (1), Furth (8), Furth and Aronson (9), Gordon (10), Griffith (15), Mudd (23), and Wilson (42). The name Mycobacterium fortuitum was introduced in 1938 by da Costa Cruz (6) for a supposedly hitherto undescribed species. The synonymity of $M$. fortuitum and $M$. ranae was established in 1969 by Stanford and Gunthorpe (31), who strongly recommended the reinstatement of $M$. ranae as the legitimate name of the species. However, acting on the request by Runyon (27), the Judicial Commission (Minutes, Judicial Commission of the ICSB, to be published) of the International Committee on Systematic Bacteriology of the International Association of Microbiological Societies has conserved the specific epithet fortuitum against ranae in the name of this organism.

The name $M$. fortuitum has not always been used correctly in the literature, and it is likely that many strains identified as belonging to $M$. fortuitum were in fact strains of $M$. chelonei Bergey et al., as suggested by Weiszfeiler et al. (40). Furthermore, there has been a tendency to use the name $M$. fortuitum as a convenient label for any rapidly growing, nonchromogenic mycobacterium isolated from clinical material.
Thus Marks (21) had advocated the use of the term "fortuitum group" for the so-called species $M$. fortuitum, $M$. peregrinum, $M$. abscessus, and $M$. borstelense.

In the taxonomic studies of Tsukamura and his colleagues (34-37), the species $M$. fortuitum is defined as including a group known as $M$. fortuitum subsp. runyonii. Strains of this group have been shown by Stanford et al. (32) to belong to the species $M$. chelonei. On the other hand, $M$. fortuitum was regarded as a species distinct from $M$. chelonei (synonym: $M$. abscessus and $M$. borstelense) and from $M$. peregrinum on the basis of agglutination serology and lipid chromatography patterns by Jenkins et al. (16). Recent studies $(18,24)$ have shown that $M$. fortuitum includes the type strains of $M$. ranae, $M$. minetti, $M$. giae, and $M$. peregrinum.

There is, therefore, a need for a redefinition of $M$. fortuitum to include all currently recognized variants of this species as well as to differentiate it from other species of rapidly growing mycobacteria. It is the purpose of this paper to reevaluate $M$. fortuitum by delineating its boundaries and ascertaining the extent and nature of variation occurring within these boundaries. For this purpose, a serological, cultural, and biochemical analysis of 100 strains of diverse origins was undertaken.

\section{MATERIALS AND METHODS}

Bacterial strains. One hundred strains of $M$. fortuitum were studied; 66 were from national and private 
culture collections and 34 were recent isolates from soil and vegetation in Uganda (34).

Cotype strains of $M$. fortuitum (ATCC 6841 [3]) and $M$. ranae (NCTC 2891 [2]), ty pe strains of $M$. giae (ATCC 11440 [7]) and $M$. peregrinum (NCTC 10264 [3]), and a strain known as $M$. minetti NCTC 3631 (25) were included. The other strains in the study were isolated over the period 1923 to 1972 and were obtained from Belgium, Brazil, Denmark, Germany, Japan, Malta, Mexico, Nigeria, Uganda, the United Kingdom, the U.S.A., and Zaire. The original designations and origins of the 100 strains are listed in Table 1.

Cultural properties. The rate of growth and pigmentation on Lowenstein-Jensen medium at 32 and $42 \mathrm{C}$ and growth on MacConkey medium at $32 \mathrm{C}$ were observed.

The morphology of colonies on $1 \%$ nutrient agar was examined by means of a plate microscope (12).

Biochemical investigations. The strains were tested for their ability to hydrolyze Tween 80 within 10 days (39), to liberate sulfate ions from phenolphthalein disulfate within 3 and 10 days (41), and to reduce nitrate to nitrite ions within 4 and $24 \mathrm{~h}(4,38)$. Strains grown on Lowenstein-Jensen medium were tested for nicotinic acid (niacin) production (17).

Utilization of carbohydrates was demonstrated by the method of Gordon and Smith (11), amidase activity by the technique of Bönicke (4), and hydrolysis of the pyrimidines cytosine, thymine, and uracil by the method of Röhrscheidt et al. (26).

Resistance to aminoglycoside antibiotics. One loopful of bacteria was suspended in $2 \mathrm{ml}$ of nutrient broth, and one loopful of this suspension was spread onto dextrose sensitivity test agar (Oxoid) containing lysed blood. After drying, disks containing streptomycin $(10 \mu \mathrm{g})$, neomycin $(10 \mu \mathrm{g})$, kanamycin $(30 \mu \mathrm{g})$, and gentamicin $(10 \mu \mathrm{g})$ were placed on the agar. Zones of inhibition were read after $48 \mathrm{~h}$ of incubation at 32 C.

Lipid chromatography. The lipid composition of the strains was studied by the technique of Marks and Szulga (22). Thin-layer plates were prepared from silica gel (BDH Laboratory reagents), and the solvent used for the chromatographic run was a mixture of 75 parts $n$-propanol, 6 parts 0.880 ammonia, and 22 parts distilled water.

Serological studies. The application of immunodiffusion analysis to the taxonomic study of mycobacteria has been described previously $(20,29,30)$. Antisera to serotypes I, II, and V of $M$. fortuitum were available from previous studies $(13,18,24,31)$, and additional antisera were prepared against a serotype III (a clinical isolate from Zaire), a serotype IV (NCTC 2006), a serotype VI (collection no. 91), and a serotype VII strain (collection no. R49).

\section{RESULTS}

Cultural properties. All strains grew within 7 days on Lowenstein-Jensen medium at $32 \mathrm{C}$, and 41 strains grew within the same period at
42 C. None of the strains were chromogenic. All strains grew on MacConkey medium at $32 \mathrm{C}$ with binding of the indicator dye. On nutrient agar, three colony types were observed, one smooth type (S) and two rough types (R1 and R2) as previously described (12). The S colonies were glossy, mucoid, and dome shaped with an entire edge. R1 colonies were flat, opaque, brittle, and rhizoid, and R2 colonies were of a waxy appearance and consistency with an undulate edge and a central papilla. Forty-three strains contained $\mathrm{S}$ colonies with varying numbers of $R 1$ and $R 2$ colonies. Twelve strains were purely of the $R 1$ type, 41 were purely of the R2 type, and 4 were a mixture of $\mathrm{R} 1$ and $\mathrm{R} 2$ colonies.

Biochemical properties. All strains hydrolyzed Tween 80 within 10 days. Arylsulfatase activity was detectable in 93 strains within 3 days and in all strains within 10 days. Ninetynine strains reduced nitrite ions within $4 \mathrm{~h}$, and one strain gave a weak reaction only after $24 \mathrm{~h}$. Niacin was not produced by any of the strains.

On the basis of carbohydrate utilization, the strains were divisible into the three biotypes of Bönicke (5). Thus, 38 strains utilizing glucose, fructose, mannose, and trehalose were of biotype A, 17 strains also utilizing mannitol and sorbitol were of biotype $B$, and 45 strains additionally utilizing inositol were of biotype C. Arabinose, dulcitol, erythritol, galactose, lactose, raffinose, rhamnose, and xylose were not utilized by any strain.

Ninety-eight strains hydrolyzed urea, 98 hydrolyzed allantoin, and 84 hydrolyzed acetamide. Other amides hydrolyzed were malonamide (eight strains), succinamide (three strains), and benzamine (one strain). The hydrolysis of isonicotinamide and pyrazinamide was extremely variable quantitatively and not readily reproducible, but almost all strains hydrolyzed these compounds to some degree. None of the strains hydrolyzed nicotinamide or salicylamide.

Cytosine was hydrolyzed by all strains but, as in the case of isonicotinamide and pyrazinamide, there was marked quantitative variation. Ten strains possessed strong thymine and uracil hydrolase activity, whereas the other strains showed no activity in this respect.

Aminoglycoside resistance. All strains were sensitive to gentamicin $(10 \mu \mathrm{g} / \mathrm{disk})$, with zone sizes of 12 to $27 \mathrm{~mm}$. Ninety-six strains were resistant to the $10 \mu \mathrm{g}$ of streptomycin per disk, and four were sensitive, with zone sizes of $24 \pm$ $1 \mathrm{~mm}$. Ninety-two strains were sensitive to neomycin $(10 \mu \mathrm{g} / \mathrm{disk})$, with zone sizes of 12 to 


\begin{tabular}{|c|c|c|c|c|}
\hline & 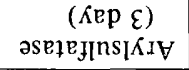 & ++++++1 & ++++++++++++++++++++ & + \\
\hline & $\cong$ & $+\ddagger$ & . & \\
\hline & $a$ & & $\ddagger$ & \\
\hline 总 & $\infty$ & 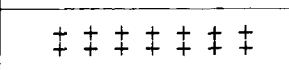 & 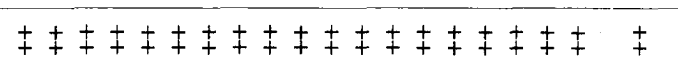 & $\ddagger$ \\
\hline 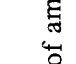 & 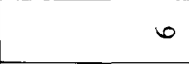 & ++++ & ++++++++++ & + \\
\hline$\stackrel{n}{2}$ & in & ++++ & ++++++++ & + \\
\hline 올 & m & 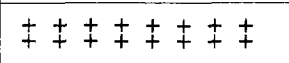 & 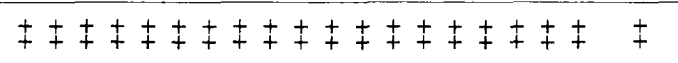 & $\ddagger$ \\
\hline & N & & & \\
\hline & - & 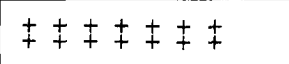 & 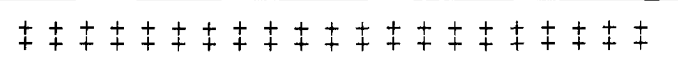 & \pm \\
\hline 「!๐? & 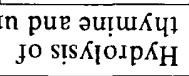 & $1+11++11$ & $1|1| 1|+1| 1|1| 1+1 \mid 1+111$ & 1 \\
\hline & ad $\kappa \nmid \circ !$ & $\ll \cup \ll \ll \cup \cup \ll \infty$ & 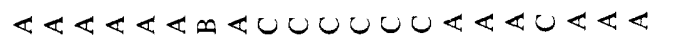 & 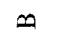 \\
\hline$\frac{1}{b}$ & 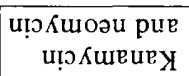 & $\sin \cos x \simeq \operatorname{ses}$ & 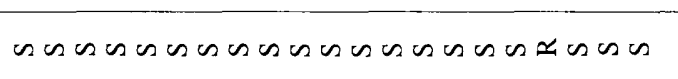 & n \\
\hline$\check{\check{\sigma}}$ & 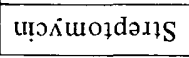 & $\simeq \backsim \simeq \simeq \backsim \simeq \simeq \simeq$ & $\simeq \simeq \simeq \simeq \simeq \simeq \sim \simeq \simeq \simeq \simeq \simeq \simeq \simeq \simeq \simeq \simeq \simeq \simeq \simeq \simeq$ & $\simeq$ \\
\hline & 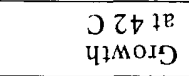 & $++++1++1$ & $++++++1+1|1| 1|1| 1|1|++++++1$ & 1 \\
\hline & 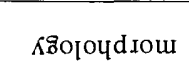 & & & $\stackrel{\mathscr{q}}{\simeq}$ \\
\hline & โย!นоOо & $\widetilde{\simeq} \operatorname{̃} \simeq \sin \approx \bar{x}$ & 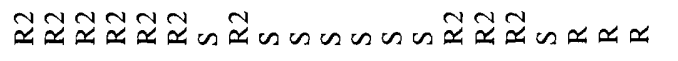 & $\bar{\simeq}$ \\
\hline & $\stackrel{00}{0}$ & 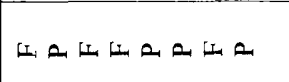 & 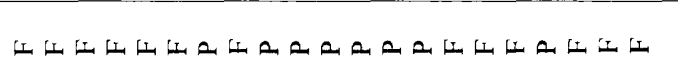 & a \\
\hline & 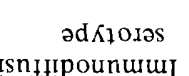 & $-\geq-ー \geq \geq->$ & 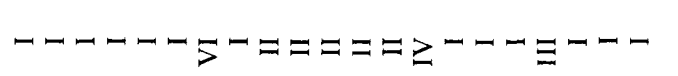 & $=$ \\
\hline & $\ddot{\nexists j}$ & 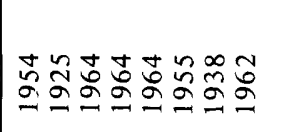 & 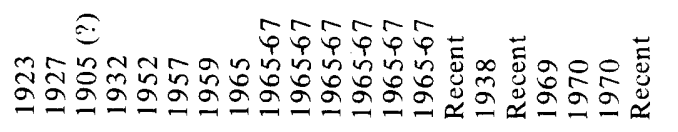 & 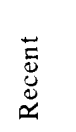 \\
\hline & 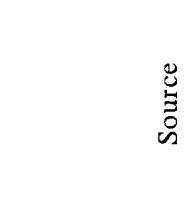 & 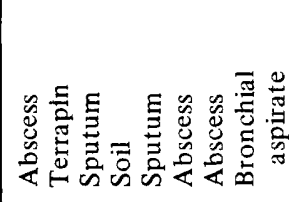 & 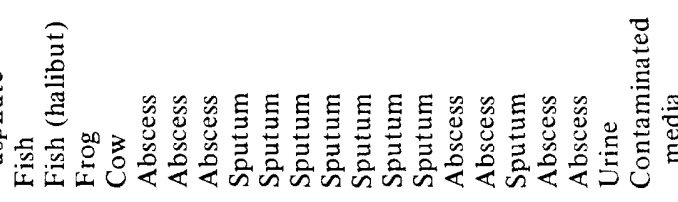 & 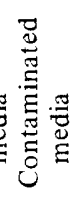 \\
\hline & 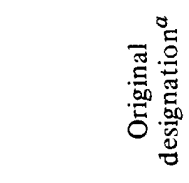 & 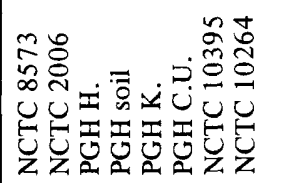 & 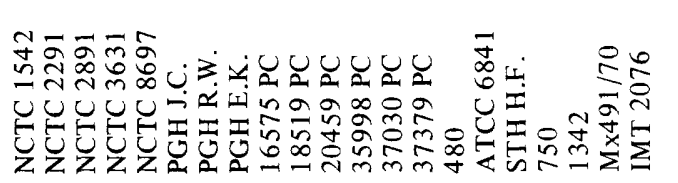 & 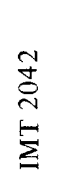 \\
\hline & 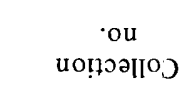 & tnorgm arg & 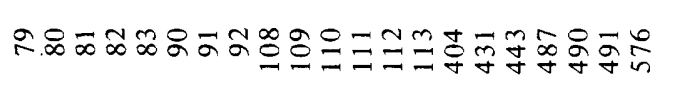 & $\stackrel{\Sigma}{n}$ \\
\hline
\end{tabular}




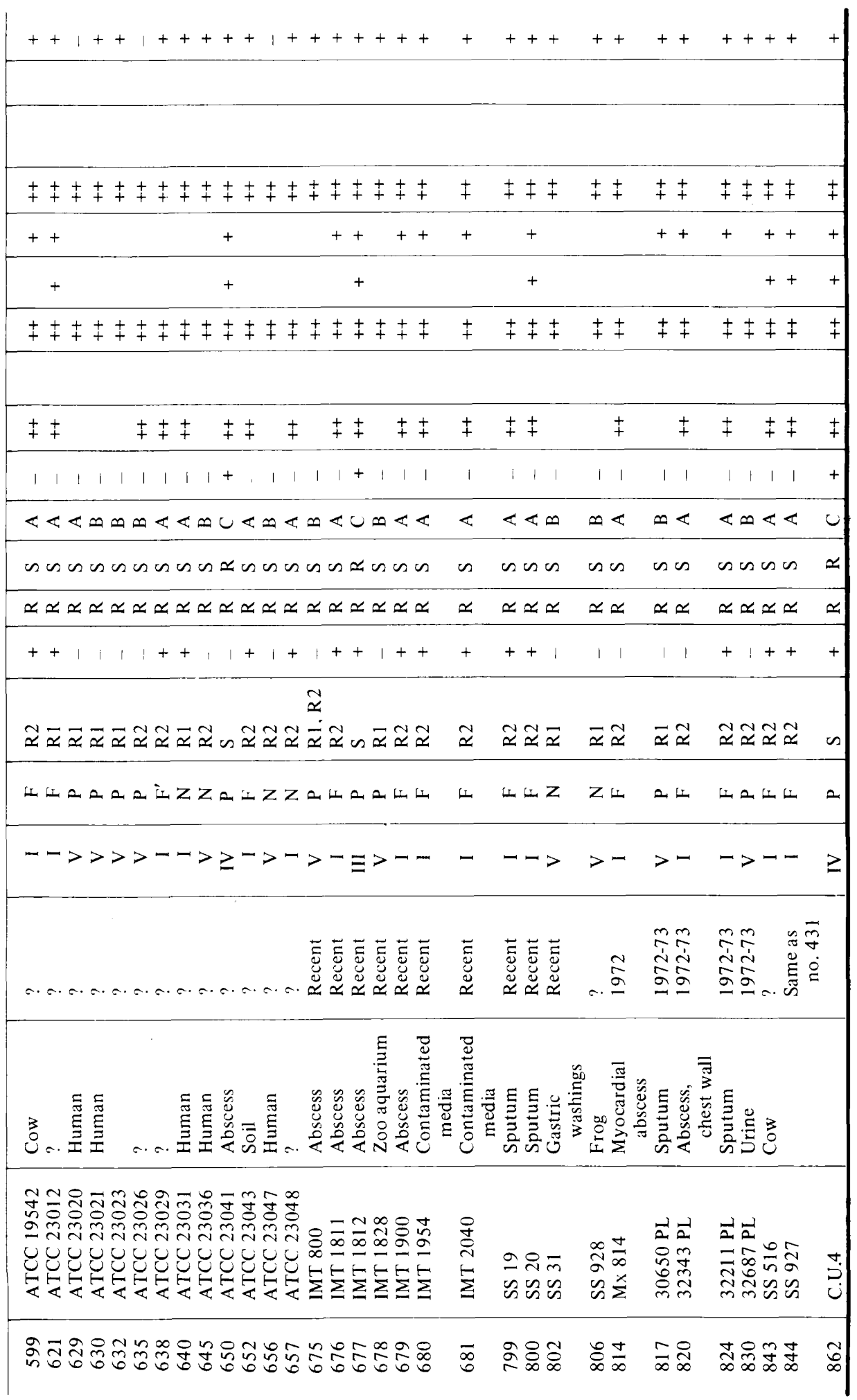




\begin{tabular}{|c|c|c|c|c|c|c|}
\hline \multicolumn{2}{|c|}{ 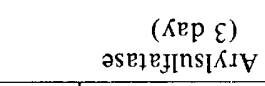 } & $+\quad+$ & $+++1++++++$ & \multirow[t]{2}{*}{+} & \multicolumn{2}{|c|}{$1+++++++\quad+$} \\
\hline \multirow{8}{*}{ 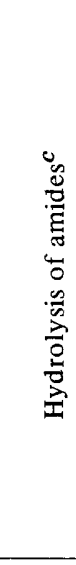 } & $\stackrel{-}{-}$ & & $\ddagger \ddagger$ & & & \\
\hline & $a$ & & & & $\ddagger$ & \\
\hline & $\infty$ & $\ddagger \ddagger$ & 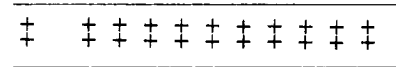 & $\ddagger$ & 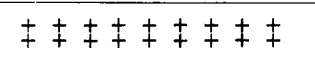 & $\ddagger$ \\
\hline & 0 & & ++++++++ & & ++++++++ & + \\
\hline & $n$ & & $+\quad+++$ & & ++++ & \\
\hline & $m$ & $\ddagger \ddagger$ & 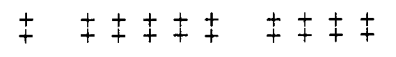 & $\ddagger$ & 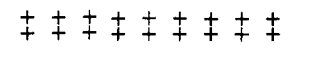 & $\ddagger$ \\
\hline & $\sim$ & & \pm & & & \\
\hline & - & $\ddagger$ & 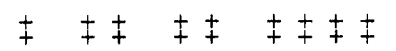 & $\ddagger$ & 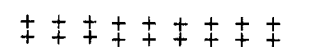 & $\ddagger$ \\
\hline \multicolumn{2}{|c|}{ 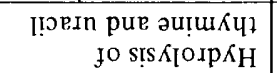 } & 11 & $\begin{array}{lllllllllll}1 & 1 & 1 & 1 & 1 & 1 & 1 & 1 & 1 & 1 & 1\end{array}$ & 1 & $\begin{array}{lllllllll}1 & 1 & 1 & 1 & 1 & 1 & 1 & 1 & 1\end{array}$ & 1 \\
\hline \multicolumn{2}{|r|}{ ad $K_{1}$ o!g } & $\ll$ & $\cup \cup \backsim \cup \backsim \cup \cup U \ll$ & $\varangle$ & 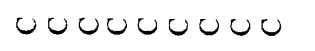 & $u$ \\
\hline \multirow{2}{*}{ 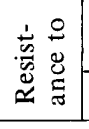 } & 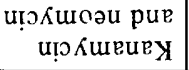 & $\infty \sim$ & ins coscososescososos & $n$ & $\cos \cos \cos c \cos \theta$ & n \\
\hline & 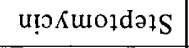 & $\simeq \quad$ os & $\sim \simeq \simeq \simeq \simeq \simeq \simeq \simeq \simeq \simeq \simeq$ & $\simeq$ & $\simeq \simeq \simeq \propto \simeq \simeq \simeq \simeq \simeq$ & $\simeq$ \\
\hline & $\begin{array}{l}3 z+18 \\
4+\sin a\end{array}$ & ++ & $\begin{array}{lllllllllll}1 & & 1 & 1 & 1 & 1 & 1 & 1 & 1 & 1 & 1\end{array}$ & + & $\begin{array}{lllllllll}1 & 1 & 1 & 1 & 1 & 1 & 1 & 1 & 1\end{array}$ & 1 \\
\hline & 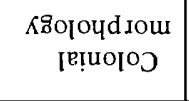 & $\approx \approx$. & 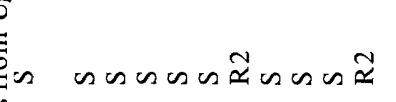 & $\widetilde{\simeq}$ & $\cos \cos \vec{x} \cos \cos c$ & 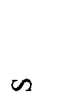 \\
\hline & 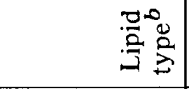 & 世地。 & 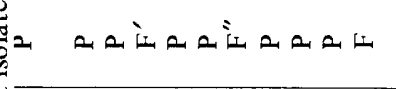 & 圷 & 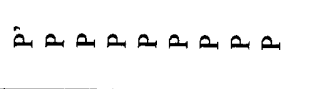 & $a$ \\
\hline \multicolumn{2}{|c|}{ 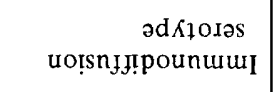 } & -- & 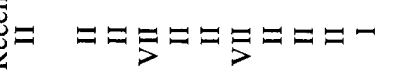 & - & $\Xi \Xi ニ ニ \Xi ニ ニ ョ ニ$ & $=$ \\
\hline & $\stackrel{\vec{\Xi}}{\nu}$ & 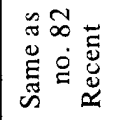 & & & & \\
\hline & $\begin{array}{l}\tilde{U} \\
\vdots \\
0 \\
\dot{n}\end{array}$ & $\overline{8}$ & 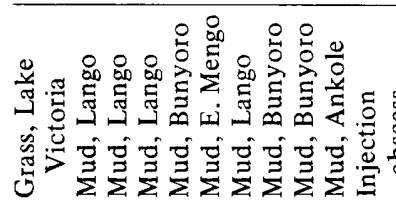 & 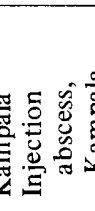 & 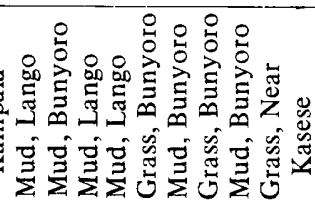 & 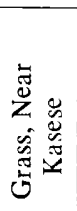 \\
\hline & 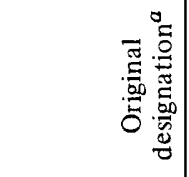 & 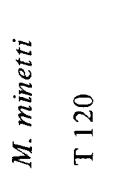 & & & & \\
\hline & 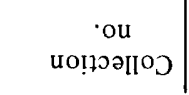 & $\underset{\infty}{\infty} \underset{\infty}{\stackrel{P}{\infty}}$ & 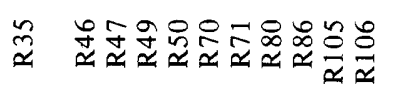 & $\Xi$ & 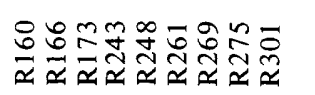 & $\begin{array}{l}m \\
\curvearrowright \\
\approx\end{array}$ \\
\hline
\end{tabular}




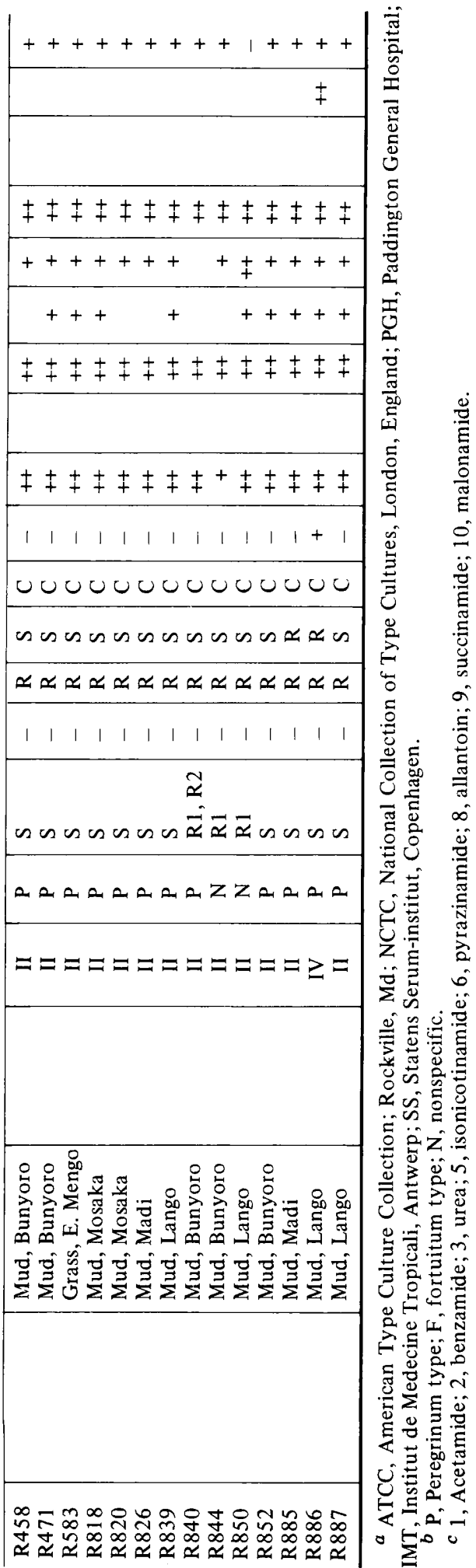

$32 \mathrm{~mm}$, and to kanamycin $(30 \mu \mathrm{g} / \mathrm{disk})$, with zone sizes of 15 to $34 \mathrm{~mm}$; the other eight strains were resistant to both antibiotics.

Lipid chromatography. Two main lipid patterns were observed corresponding to the $F$ (Fortuitum) and $\mathbf{P}$ (Peregrinum) patterns described by Jenkins et al. (16). Fifty-four strains were of the $\mathbf{P}$ type, 38 were of the $F$ type, and 8 showed no specific lipid pattern. Three of the $F$ types showed minor variations: two had an extra orange spot $\left(F^{\prime}\right)$, and one had an extra sky-blue spot $\left(\mathrm{F}^{\prime \prime}\right)$.

Immunodiffusion serology. As described in previous studies $(29,31)$, the precipitation lines were divisible into three groups: those shared with all other mycobacteria (group i antigens), those shared with other rapid growers (group iii), and species-specific antigens (group iv). In this study, nine group iv antigens were observed, but no strain possessed more than six. Three of these antigens were present in each of the 100 strains studied. On the basis of the variable possession of the other six antigens, seven serotypes were determined, five of which have been described previously $(12,18,24)$. The use of antisera to serotypes III and IV has confirmed the antigenic structure of serotype IV but has shown that the serotype III strains possess an extra antigen peculiar to themselves. Two additional types, VI and VII, were determined; these contained one and two strains, respectively. Their antigenic structure has been confirmed by the use of type-specific antisera. The antigenic structures of the seven serotypes are shown in Fig. 1.

Thirty-eight strains were of serotype I, 35 were of serotype II, 2 were of serotype III, 7 were of serotype IV, 13 were of serotype V, 1 was of serotype VI, and 2 were of serotype VII.

The cotype strains of $M$. fortuitum and $M$. ranae, and a strain referred to as $M$. minetti, were of serotype I, and the type strains of $M$.

\section{SEROTYPE}

$$
\begin{gathered}
\text { I } \\
\text { II } \\
\text { III } \\
\text { IV } \\
\text { V } \\
\text { VI } \\
\text { VII }
\end{gathered}
$$

FIG. 1. Species-specific antigens of Mycobacterium fortuitum. 
giae and $M$. peregrinum were of serotype V.

The variable characteristics of the 100 strains of $M$. fortuitum are shown in Table 1. The correlation of these variable characteristics is shown in Table 2. A summary of the constant and variable characteristics is provided in Table 3 .

\section{DISCUSSION}

The results of this and previous studies have shown that there is considerable cultural, biochemical, and antigenic variation within the serologically defined species $M$. fortuitum. Table 2 shows the variation found within each serotype. A close correlation exists between the various properties listed. Thus, all serotype I strains failed to utilize the alcoholic sugars inositol, mannitol, and sorbitol; all strains of serotypes V, VI, and VII utilized mannitol and sorbitol; and, with a single exception, the strains of serotype II, III, and IV utilized inositol. The lipid patterns are also related to serotype, the Fortuitum pattern (16) occurring in serotypes I and VII and the Peregrinum pattern in the other serotypes. Naturally occurring resistance to kanamycin and neomycin, which is due to enzymatic degradation of the drugs (14), is restricted to serotypes III and IV. Such resistance correlates closely with thymine and uracil hydrolase activity: the ten strains that hydrolyze these pyrimidines include the eight strains that are resistant to kanamycin and neomycin. The other two strains possess strong succinamidase activity, the significance of which is unknown. Colonial morphology is partly related to serotype: thus, $S$ forms occur only in serotypes II, III, IV, VI, and VII, and, of the 38 serotype I strains, 36 are of the R2 type.

Studies on single, smooth colony isolates have shown that irreversible smooth-to-rough variation occurs (12). However, in the majority of cases such variation is not accompanied by

\section{TABLE 3. Characteristics of Mycobacterium fortuitum encountered in diagnostic bacteriology}

\begin{tabular}{cc}
\hline & $\begin{array}{c}\text { Percent of } \\
\text { strains }\end{array}$ \\
Characteristic & positive \\
\hline
\end{tabular}

Growth within 7 days on Lowenstein-

Jensen medium at $32 \mathrm{C} \ldots \ldots \ldots \ldots \ldots$

Growth on MacConkey medium with binding

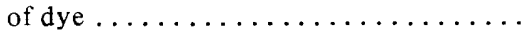

Nitratase activity within $24 \mathrm{~h} \ldots \ldots . \ldots 100$

Tween 80 hydrolysis within 10 days ..... 100

Arylsulfatase activity within 10 days ..... 100

Utilization of glucose, mannose,

trehalose, and fructose . . . . . . . . 100

Hydrolysis of cytosine .............. 100

Pigment production in light and dark .... 0

Production of niacin ............. 0

Hydrolysis of nicotinamide and salicylamide 0

Utilization of arabinose, dulcitol, erythritol, lactose, galactose, raffinose, rhamnose,

and xylose $\ldots \ldots \ldots \ldots \ldots \ldots \ldots \ldots$

Growth at $42 \mathrm{C} \ldots \ldots \ldots \ldots \ldots \ldots \ldots .41$

Resistance to kanamycin and neomycin ... 8

Arylsulfatase activity within 3 days . . . . . 93

Hydrolysis of thymine and uracil . . . . . . 10

Hydrolysis of urea ............... 98

Hydrolysis of allantoin ........... 98

Hydrolysis of acetamide ............ 84

Hydrolysis of malonamide .......... 8

Hydrolysis of succinamide .......... 3

Hydrolysis of benzamide ............ 1

Utilization of mannitol and sorbitol ..... 62

Utilization of inositol ............ 45

TABLE 2. Occurrence of the variable properties of Mycobacterium fortuitum in the seven immunodiffusion serotypes

\begin{tabular}{|c|c|c|c|c|c|c|c|c|c|c|c|c|c|c|c|}
\hline \multirow[b]{2}{*}{$\begin{array}{l}\text { Sero- } \\
\text { type }\end{array}$} & \multirow[b]{2}{*}{$\begin{array}{l}\text { No. of } \\
\text { strains }\end{array}$} & \multicolumn{3}{|c|}{ Lipid type ${ }^{a}$} & \multicolumn{4}{|c|}{ Colony type } & \multirow{2}{*}{$\begin{array}{c}\text { Resistance to } \\
\text { kanamycin } \\
\text { and neomycin }\end{array}$} & \multirow[b]{2}{*}{$\begin{array}{l}\text { Growth } \\
\text { at } 42 \mathrm{C}\end{array}$} & \multicolumn{3}{|c|}{$\begin{array}{c}\text { Utilization } \\
\text { of carbohydrates }\end{array}$} & \multicolumn{2}{|c|}{ Hydrolysis of } \\
\hline & & $\mathrm{P}$ & $\mathrm{F}$ & $\mathrm{N}$ & $S$ & R1 & $\mathrm{R} 2$ & $\mathrm{R} 1 / \mathrm{R} 2$ & & & $\begin{array}{l}\text { Ino- } \\
\text { sitol }\end{array}$ & $\begin{array}{l}\text { Man- } \\
\text { nitol }\end{array}$ & $\begin{array}{l}\text { Sor- } \\
\text { bitol }\end{array}$ & $\begin{array}{l}\text { Thy- } \\
\text { mine }\end{array}$ & $\begin{array}{l}\text { Acet- } \\
\text { amide }\end{array}$ \\
\hline I & 38 & & $36^{b}$ & 2 & & 2 & 36 & & & 35 & & & & & 37 \\
\hline II & 37 & 35 & & 2 & 32 & 3 & & 2 & & & 36 & 37 & 37 & & 36 \\
\hline III & 2 & 2 & & & 2 & & & & 2 & 2 & 2 & 2 & 2 & 2 & 2 \\
\hline IV & 7 & 7 & & & 7 & & & & 6 & 3 & 7 & 7 & 7 & 7 & 7 \\
\hline V & 13 & 9 & & 4 & & 7 & 4 & 2 & & & & 13 & 13 & & 1 \\
\hline VI & 1 & 1 & & & 1 & & & & & 1 & & 1 & 1 & 1 & 1 \\
\hline VII & 2 & & $2^{c}$ & & 1 & & 1 & & & & & 2 & 2 & & \\
\hline Total & 100 & 54 & 38 & 8 & 43 & 12 & 41 & 4 & 8 & 41 & 45 & 62 & 62 & 10 & 84 \\
\hline
\end{tabular}

\footnotetext{
${ }^{a}$ P, Peregrinum type: F, Fortuitum type; N, nonspecific.

$b$ Includes one strain of lipid type $F^{\prime}$.

$c$ Two strains of lipid types $\mathrm{F}^{\prime}$ and $\mathrm{F}^{\prime \prime}$.
} 
change in immunodiffusion serotype or biotype and is thus analogous to the simple smooth-torough variation that occurs in many other bacterial genera.

The major patterns of intraspecific variation are shown in Table 4 according to serotype. Strains of serotypes III and IV cannot be distinguished from each other culturally or biochemically but differ from all other types in giving the most positive reactions. In contrast, strains of serotypes $\mathrm{I}$ and $\mathrm{V}$ in particular differ from the biotype $C$ strains (serotypes II, III, and IV) by the lack of several characteristics. In a previous study (12), it was shown that strains of serotypes $\mathrm{I}$ and $\mathrm{V}$ could be derived at low frequency from a genetically more complete serotype II strain. As this change was irreversible, it was concluded that a major mutation, probably deletional, had occurred. It was postulated that such mutation could play an important role in the origin of intraspecific variants in this and other mycobacterial species. Such a concept would also explain the occurrence of forms intermediate between the major variants which could arise by small deletions or point mutations. For example, one serotype IV strain was sensitive to kanamycin and neomycin, a serotype II strain failed to utilize inositol, and another failed to hydrolyze acetamide.

Although a large number of strains of diverse geographical origin have been examined, it is probable that additional variants exist, some of which may be of limited geographical distribution. The strains of serotypes I, II, IV, and V studied were from widely distributed areas throughout the world, but the two serotype III strains were isolated near Kinshasa, Zaire, and the two type VII strains came from mud in the Lango district of Uganda. Some of the minor variations within the species may be associated with lysogeny. Despite the extent of variation within $M$. fortuitum, there are, of course, many properties constant for this species so that the strains form a distinct cluster on numerical analysis (18). Although there are some points of similarity between serotype I strains of $M$. fortuitum and strains of $M$. chelonei, there is no reason for confusion to occur. Both groups of strains utilize glucose, mannose, and trehalose at $28 \mathrm{C}$, but strains of $M$. chelonei are unable to do sc at $40 \mathrm{C}$; in addition, the latter are unable to reduce nitrate or hydrolyze allantoin, do not grow at $42 \mathrm{C}$, differ in colonial morphology, and possess a different lipid pattern. On immunodiffusion analysis, they bear no closer relationship to $M$. fortuitum than to any other rapidly growing mycobacterium (32).

The strains analyzed in this study were isolated from humans and other animals and from environmental sources. Those isolated from human sources were divisible into two groups: those clearly associated with disease, i.e., the only pathogen isolated from abscesses, and those isolated from sputum or urine with no proven association with disease. Table 5 shows the distribution of strains according to these groups and to the serotypes. Strains of serotype I are most commonly associated with disease, whereas no definite cases of disease are attributed to strains of serotype II. It is of some relevance that the great majority of strains isolated from the Ugandan environment were of serotype II, whereas two strains isolated from injection abscesses from the same geographical area were both of serotype I. It is also noteworthy that the type strains are all of either serotype I or V, probably because until recently the great majority of mycobacteria in culture collections were isolated from clinical material rather than from the environment.

We do not consider that all the variants described merit subspecific status. However, it

TABLE 4. Summarized correlation of the variable characteristics of Mycobacterium fortuitum

\begin{tabular}{|c|c|c|c|c|c|c|c|}
\hline \multirow[b]{2}{*}{ Serotype } & \multirow[b]{2}{*}{ Biotype $^{a}$} & \multirow{2}{*}{$\begin{array}{l}\text { Colony } \\
\text { morphology }\end{array}$} & \multirow{2}{*}{$\begin{array}{l}\text { Lipid } \\
\text { type }^{b}\end{array}$} & \multirow{2}{*}{$\begin{array}{l}\text { Growth } \\
\text { at } 42 \mathrm{C}\end{array}$} & \multirow{2}{*}{$\begin{array}{c}\text { Resistance } \\
\text { to neomycin } \\
\text { and kanamycin }\end{array}$} & \multicolumn{2}{|c|}{ Hydrolysis of } \\
\hline & & & & & & Thymine & Acetamide \\
\hline I & A & $\mathrm{R} 2$ & $\mathrm{~F}$ & + & - & - & + \\
\hline II & $\mathrm{C}$ & S & $\mathbf{P}$ & - & - & - & + \\
\hline III & $\mathrm{C}$ & S & $\mathbf{P}$ & + & + & + & + \\
\hline IV & $\mathrm{C}$ & $\mathrm{S}$ & $\mathbf{P}$ & + & + & + & + \\
\hline V & $\mathrm{B}$ & $\mathrm{R} 1, \mathrm{R} 2$ & $P$ & - & - & - & - \\
\hline VI & B & $\mathrm{S}$ & $\mathbf{P}$ & + & - & + & + \\
\hline VII & B & $\mathrm{S}, \mathrm{R} 2$ & $\mathrm{~F}^{c}$ & - & - & - & - \\
\hline
\end{tabular}

${ }^{a}$ Biotypes of Bönicke (1966).

$b$ P, Peregrinum type; F, Fortuitum type.

$c F^{\prime}$ and $F^{\prime \prime}$ strains. 
TABLE 5. Origin of the strains of Mycobacterium fortuitum according to immunodiffusion serotype

\begin{tabular}{|c|c|c|c|c|c|c|}
\hline \multirow[b]{2}{*}{ Serotype } & \multicolumn{2}{|c|}{ Disease } & \multirow{2}{*}{$\begin{array}{l}\text { Clinical } \\
\text { material }\end{array}$} & \multirow[b]{2}{*}{ Environment } & \multirow{2}{*}{$\begin{array}{l}\text { Contaminated } \\
\text { media }\end{array}$} & \multirow[b]{2}{*}{ Unknown } \\
\hline & Human & Animal & & & & \\
\hline I & 14 & 6 & 9 & 3 & 3 & 3 \\
\hline II & & & 5 & 31 & 1 & \\
\hline III & 2 & & & & & \\
\hline IV & 3 & 1 & 2 & 1 & & \\
\hline $\mathrm{V}$ & 2 & 1 & 8 & 1 & & 1 \\
\hline VI & 1 & & & & & \\
\hline VII & & & & 2 & & \\
\hline
\end{tabular}

has been suggested by Pattyn et al. (24) that the names $M$. fortuitum subsp. fortuitum and $M$. fortuitum subsp. giae ( $M$. peregrinum) be applied to strains of serotypes I and $\mathrm{V}$, respectively. In view of the close correlation between the biotypes of Bönicke and other variable properties, this typing system may be used to advantage as an alternative, with division of the biotypc $\mathrm{C}$ strains into those sensitive and those resistant to neomycin and kanamycin. Additional methods for the subdivision of $M$. fortuitum are available. The use of agglutination serology and delayed hypersensitivity reactions in guinea pigs have been described previously (24). The species may also be subdivided by means of bacteriophage typing (13).

Now that $M$. fortuitum is the correct name for a well-defined mycobacterial species, it is hoped that in the future it will be used as such and not as a broad term for any rapidly growing, nonchromogenic mycobacterium isolated from clinical material, which has frequently been the case in the past.

\section{ACKNOWLEDGMENTS}

We are grateful to the many bacteriologists who have supplied bacterial strains. We are especially grateful to Roger C. Paul, who supplied the isolates from Uganda.

\section{REPRINT REQUESTS}

Address reprint requests to: Dr. J. M. Grange, The School of Pathology, The Middlesex Hospital Medical School, Riding House Street, London, W1P 7LD, England.

\section{LITERATURE CITED}

1. Aronson, J. D. 1929. Spontaneous tuberculosis in snakes. J. Infect. Dis. 44:215-223.

2. Bergey, D. H., F. C. Harrison, R. S. Breed, B. W.
Hammer, and F. M. Huntoon. 1923. Manual of determinative bacteriology, 1 st ed. Williams \& Wilkins Co., Baltimore.

3. Bojalil, L. F., J. Cerbon, and A. Trujillo. 1962. Adansonian classification of Mycobacteria. J. Gen. Microbiol. 28:333-346.

4. Bönicke, R. 1962. Identification of mycobacteria by biochemical methods. Bull. Int. Union Tuberc. 32:13-68.

5. Bönicke, R. 1966. The occurrence of atypical mycobacteria in the environment of man and animal. Bull. Int. Union Tuberc. 37:361-368.

6. Cruz, J. daC. 1938. Mycobacterium fortuitum, un novo bacilo acidoresistente patogenico para o homen. Acta Med. (Rio de Janeiro) 1:297-301.

7. Darzins, E. 1950. Tuberculose das gias (Leptodactylus pentadactylus). Arch. Inst. Bras. Invest. Tuberc. 9:29-37.

8. Furth, J. 1926. On the serological relationship of acid-fast bacteria. J. Immunol. 12: 273-292.

9. Furth, J., and J. D. Aronson. 1927. On the specificity of the alcohol soluble substances of acid-fast bacteria. J. Immunol. 13:265-271.

10. Gordon, R. E. 1937. The classification of acid-fast bacteria. J. Bacteriol. 34:617-630.

11. Gordon, R. E., and M. M. Smith. 1953. Rapidly growing, acid fast bacteria. I. Species' descriptions of Mycobacterium phlei Lehmann and Neumann and Mycobacterium smegmatis (Trevisan) Lehmann and Neumann. J. Bacteriol. 66:41-48.

12. Grange, J. M. 1973. Intra-specific variation in the mycobacteria - a taxonomic aid. Ann. Soc. Belg. Med. Trop. Parasitol. Mycol. Hum. Anim. 53:339-346.

13. Grange, J. M., and G. Nordstrom. 1973. Bacteriophage typing of Mycobacterium ranae (fortuitum). The correlation of lysis by mycobacteriophage BK4 and inositol utilization. Acta Pathol. Microbiol. Scand. Sect. B 81:408-412.

14. Grange, J. M., and G. Nordstrom. 1974. Kanamycin and Neomycin resistance in Mycobacterium ranae (fortuitum) associated with serological and biochemical markers. Zentrabl. Bakteriol. Parasitenk. Infektionskr. Hyg. Abt. Orig. 226: 369-375.

15. Griffith, A. S. 1930. A system of bacteriology. Medical Research Council, H. M. Stationery Office, London.

16. Jenkins, P. A., J. Marks, and W. B. Schaefer. 1971. Lipid chromatography and seroagglutination in the classification of rapidly growing 
mycobacteria. Amer. Rev. Resp. Dis. 103:179187.

17. Konno, K. 1956. New chemical method to differentiate human type tubercle bacilli from other mycobacteria. Science 129:985.

18. Kubica, G. P., I. Baess, R. E. Gordon, P. A. Jenkins, J. B. G. Kwapinski, C. McDurmont, S. R. Pattyn, H. Saito, V. A. Silcox, J. L. Stanford, K. Takeya, and M. Tsukamura 1972. A co-operative numerical analysis of rapidly growing mycobacteria. J. Gen. Microbiol. 73:55-70.

19. Küster, E. 1905. Über Kaltbluttuberculose. Muenchen Med. Wochenschr. 52:57-59.

20. Lind, A. 1959. Serological studies of Mycobacteria by means of the diffusion-in-gel technique. Int. Arch. Allergy 14:264-278.

21. Marks, J. 1970. New mycobacteria. Health Trends 2:68-69.

22. Marks, J., and T. Szulga. 1965. Thin-layer chromatography of mycobacterial lipids as an aid to classification: technical procedures, Mycobacterium fortuitum. Tubercle 46:400-411.

23. Mudd, S. 1925. A study by new methods of the surfaces of normal and sensitized acid-fast bacteria. Proc. Soc. Exp. Biol. Med. 23:569-572.

24. Pattyn, S. R., M. Magnusson, J. L. Stanford, and J. M. Grange. 1973. A study of Mycobacterium ranae (fortuitum). J. Med. Microbiol. 7:67-76.

25. Penso, G., G. Castelnuovo, A: Gaudiano, M. Princivalle, L. Vella, and A. Zampieri. 1952. Studi e ricerche sui micobatteri. VIII. Un nuovo baccilo tuberculare; il Mycobacterium minetti n. sp-studio microbiologico e patogenetico. Rend. Ist. Super. Sanita 15:491-548.

26. Röhrscheidt, E., Zs. Tarnok, and I. Tarnok. 1970. Purin- und pyrimidinabbauende Enzyme in Mycobakterien und Nocardien. Zentrabl. Bakteriol. Parasitenk. Infectionskr. Hyg. Abt. Orig. 215:550554.

27. Runyon, E. H. 1972. Conservation of the specific epithet fortuitum in the name of the organism known as Mycobacterium fortuitum da Costa Cruz. Int. J. Syst. Bacteriol. 22:50-51.

28. Rupprecht, J. 1904. Uber saurefeste Bazillen nebst Beschreibung eines Falles von spontaner Froschtuberculose. Ernst Heinrich Moritz, Stuttgart.

29. Stanford, J. L.・1973. Immunodiffu sion analysis - a rational basis for the taxonomy of mycobacteria. Ann. Soc. Belg. Med. Trop. Parasitol. Mycol. Hum. Anim. 53:321-330.

30. Stanford, J. L., and A. Beck. 1968. An antigenic analysis of the mycobacteria. J. Pathol. Bacteriol. 95:131-139.

31. Stanford, J. L., and W. J. Gunthorpe. 1969. Serological and bacteriological investigation of Mycobacterium ranae. J. Bacteriol. 88:375-383.

32. Stanford, J. L., S. R. Pattyn, F. Portaels, and W. J. Gunthorpe. 1972. Studies on Mycobacterium chelonei. J. Med. Microbiol. 5:177-182.

33. Stanford, J. L., and R. C. Paul. 1973. A preliminary report on some studies of environmental mycobacteria from Uganda. Ann. Soc. Belg. Med. Trop. Parasitol. Mycol. Hum. Anim. 53:389-393.

34. Tsukamura, M. 1967. Identification of mycobacteria. Tubercle 48:311-338.

35. Tsukamura, M. 1971. Some considerations on classification of mycobacteria. Jap. J. Tuberc. Chest Dis. 17:18-30.

36. Tsukamura, M., S. Mizuno, and S. Tsukamura. 1968. Classification of rapidly growing mycobacteria. Jap. J. Microbiol. 12:151-166.

37. Tsukamura, M., S. Tsukamura, and S. Mizuno. 1967. Numerical taxonomy of Mycobacterium fortuitum. Jap. J. Microbiol. 11:243-253.

38. Virtanen, S. 1960. A study of nitrate reduction by mycobacteria: the use of the nitrate-reduction test in the identification of Mycobacteria. Acta Tuberc. Scand. 48 Suppl.:1-119.

39. Wayne, L. G., J. R. Doubek, and L. Russel. 1964. Classification and identification of Mycobacteria. 1. Tests employing Tween 80 as substrate. Amer. Rev. Resp. Dis. 90:588-597.

40. Weiszfeiller, J. G., V. Karasseva, and E. Karczag. 1969. Comparative studies on the taxonomic relationship between Mycobacterium abscessus and Mycobacterium borstelense. Acta Microbiol. Acad. Sci. Hung. 16:371-379.

41. Whitehead, J. E. M., P. Wildy, and H. C. Engbaek. 1953. Arylsulfatase activity of mycobacteria. J. Pathol. Bacteriol. 65:451-460.

42. Wilson, G. S. 1925. The serological classification of the tubercle bacilli by agglutination and absorbtion of agglutinins. J. Pathol. Bacteriol. 28:69-96. 